\title{
Pengaruh Media Sosial untuk Membantu Meningkatkan Kemampuan Menulis Bahasa Jepang
}

\author{
${ }^{1}$ Linna Meilia Rasiban, ${ }^{2}$ Ahmad Dahidi, ${ }^{3}$ Renariah Renariah \\ Universitas Pendidikan Indonesia, Indonesia \\ 1linnameilia@upi.edu \\ 2ahmaddahidi@upi.edu \\ 3renariah@upi.edu
}

DOI: $10.18196 /$ jjlel.4241

\begin{abstract}
Abstrak
Penelitian ini menyelidiki pengaruh media sosial terhadap kemampuan menulis bahasa Jepang. Berbagai studi tentang efek media sosial pada siswa sudah banyak dilakukan. Tapi penelitian ini lebih difokuskan pada bagaimana media sosial dapat mempengaruhi keterampilan menulis dan mengembangkan menulis kreatif pada pembelajar dewasa khususnya pembelajar bahasa Jepang sebagai bahasa asing. Pada penelitian ini media sosial yang digunakan dibatasi hanya menggunakan media email, WhatsApp dan Line. Berdasarkan hasil angket pada studi pendahuluan menunjukkan bahwa ketiga media sosial ini yang paling sering digunakan mahasiswa khususnya mahasiswa bahasa Jepang pada saat berkomunikasi dengan dosen atau teman orang Jepang. Metode penelitian yang digunakan adalah metode eksperimen melalui kuesioner online dan menganalisis dari bukti autentik email, WhatsApps dan Line yang dikembangkan untuk mengeksplorasi pandangan siswa yang berpartisipasi mengenai media sosial, adopsi mereka terhadap media sosial untuk tujuan penelitian, dan pengaruhnya dalam mengembangkan keterampilan menulis bahasa Jepang. Partisipan yang mengikuti penelitian ini sebanyak 25 mahasiswa yang telah belajar bahasa Jepang rata-rata 3-4 tahun. Berdasarkan hasil survey dan hasil analisis angket, disimpulkan bahwa email, WhatsApp dan Line membantu dalam memperlancar dan mengembangkan kegiatan menulis terutama dalam pemahaman dari feedback yang dilakukan antara mahasiswa dan dosennya.
\end{abstract}

Kata kunci: keterampilan menulis; media sosial; metode survei; peer learning; second language writing 


\begin{abstract}
This study investigated the effect of social media on Japanese writing skills. Various studies regarding the effects of social media on the students have been conducted before. Yet, this research was more focused on how social media could influence writing skills and develop creative writing in adult learners, especially learners of Japanese as a foreign language. In this research, the social media used was limited to email, WhatsApp and Line. Based on the results of the questionnaire in the preliminary study, it showed that these three social media platforms were the most used by students frequently, especially the Japanese students when they were communicating with Japanese lecturers or friends. The research used the experiment method. The data was gained by giving online questionnaires and analyzing the authentic evidence of email, WhatsApps and Line which was developed to explore the views of participating students about social media, their adoption of social media for research purposes, and its influence in developing Japanese writing skills. The research participants were 25 undergraduate students who had been studying Japanese for about 3-4 years. Based on the survey results and the questionnaire analysis, it could be concluded that e-mail, WhatsApp and Line were very helpful in developing students' writing skills, especially in terms of understanding the feedback given by the lecturers.
\end{abstract}

Keywords: writing skills; social media; survey methods; peer learning; second language writing

\title{
PENDAHULUAN
}

Menulis dianggap penting bagi pembelajar dewasa khususnya sebagai pembelajar bahasa asing karena dalam kegiatan perkuliahan mereka banyak tugas yang dilakukan dengan kegiatan menulis termasuk menulis hasil penelitian dan artikel. Tetapi pembelajar biasanya dihadapkan dengan banyak tantangan dalam tulisan mereka ketika menggunakan bahasa kedua (Ellis dan Schmidt, 1997). Beberapa menunjukkan ada beberapa kesulitan yang dialami pembelajar dalam menulis akademik (academic writing), yaitu pemahaman dan konsep ide, komposisi, akurasi bahasa, ketepatan penggunaan kosakata dan kurangnya waktu (Grabe \& Kaplan, 1996; Yahya \& Hasyim, 2013).

Kompleksitas penulisan kedua bahasa ini diperparah oleh kesulitan belajar individu dari bahasa kedua (selanjutnya disebut L2), dan seberapa mirip atau tidaknya keterampilan literasi pertama dalam kompatibilitas 
dengan bahasa pertama (selanjutnya disebut L1) (Ellis dan Schmidt, 1997). Hal tersebut yang menjadi kesulitan tersendiri bagi pembelajar bahasa asing, terutama bagi pembelajar yang berbeda latar belakang sistem penulisannya. Mayoritas pembelajar bahasa Jepang sebagai L2 terutama bagi pembelajar yang berlatar belakang sistem penulisannya non-kanji menganggap kanji adalah satu aspek yang paling menantang (challenging) dalam mempelajari bahasa Jepang (Gamage, 2003; Mori, 2008; Mori \& Shimizu, 2007; Okita, 1997; Toyoda, 1995, 1998).

Hal ini diperkuat dari hasil tes awal yang dilakukan (Februari 2019) pada mahasiswa bahasa Jepang semester 4 yang menunjukkan bahwa mayoritas mahasiswa masih kesulitan mengembangkan ide cerita yang dituangkan pada kerangka karangan kemudian dikembangkan ke dalam karangan/tulisan utuh dan belum terampil dalam merangkai kalimat sehingga koherensi antar kalimat masih belum baik.

Beberapa penelitian menunjukkan bahwa persepsi mahasiswa mengenai penggunaan media sosial memberikan pengaruh yang positif dalam kegiatan menulis (Shazali, Shamsudin, \& Yunus, 2019). Menurut Sakkir (2016, 2018) menyatakan bahwa salah satu strategi yang menarik bagi peserta didik secara tertulis dipilih adalah media sosial. Media ini diharapkan dapat meningkatkan minat siswa dan motivasi dalam menulis (Sakkir, 2016, Sakkir, 2018).

Media sosial adalah alat yang dimediasi computer yang memungkinkan seseorang untuk mengkreasikan, berbagi ide, bertukar informasi dan gambar atau video dalam komunitas virtual melalui jaringan internet (Boyd \& Ellison, 2007; Sakkir \& Abrar, 2018). Media sosial dipercaya lahir sebagai media teknologi yang sangat berguna untuk komunikasi pribadi (Tess, 2013). Pemilihan media sosial sebagai perantara alat komunikasi untuk mempermudah mahasiswa untuk menyampaikan ide dan masalahnya dalam kegiatan menulis. Selain itu media ini sangat familiar dan sering digunakan bahkan tidak dapat dipisahkan oleh mahasiswa saat ini. 
Media sosial yang digunakan pada penelitian ini adalah email, WhatsApps, dan Line. Berdasarkan angket yang disebarkan kepada mahasiswa Departemen Pendidikan Bahasa Jepang (Februari 2019) menunjukkan bahwa media sosial yang banyak digunakan mahasiswa adalah WhatsApps, dan Line.

Penggunaan media sosial sebagai alat perantara untuk meningkatkan kemampuan menulis dapat memberikan efek positif pada kemajuan menulis peserta didik (Bakeer, 2018; Sakkir \& Abrar, 2018; Shazali dkk., 2019). Meskipun demikian, penelitian yang menggunakan sumber datanya email, WhatsApps, dan Line masih sedikit. Penelitian ini bertujuan untuk memperluas kajian media sosial yang dapat memberikan pengaruh pada kemampuan menulis.

Berdasarkan hasil penelitian sebelumnya dapat disimpulkan bahwa model pembelajaran Project Based Learning (selanjutnya disingkat PBL) dapat meningkatkan motivasi dan dapat mengembangkan ide karangan, tetapi masih ditemukan kekurangan yaitu ada hal yang muncul setelah berhasil mengembangkan ide ke dalam karangan, yaitu mayoritas mahasiswa hanya dapat menuliskan kalimat-kalimat sederhana dengan pola kalimat dan kosakata dasar yang mudah diingatnya saja, kemampuan mahasiswa dalam menuliskan kalimat panjang dan majemuk dinilai sangat kurang, kemampuan dalam penulisan akademik seperti penguasaan tata bahasa dan pola kalimat serta perbendaharaan kosa kata yang dimiliki mahasiswa masih kurang (Sutjiati \& Rasiban, 2016; Yahya \& Hasyim, 2013).

Untuk solusi dari mengatasi masalah tersebut yaitu dengan mengkolaborasikan model pembelajaran PBL dengan teknik Peer Feedback. Alsan mengkolaborasikan kedua teknik ini untuk memberikan pendampingan dan control dari pengajar kepada mahasiswa dengan memberikan evaluasi dan feedback secara langsung dari hasil karangan yang telah dibuatnya. Hal ini sejalan seperti yang telah diungkapkan oleh Hyland (1998), Hyland \& Hyland (2001) bahwa tugas yang paling penting dari pengajar mata kuliah Menulis 
adalah kegiatan memberikan feedback tertulis terhadap hasil karangan yang telah dibuat oleh mahasiswanya.

Berdasarkan identifikasi masalah tersebut di atas, fokus pertanyaan penelitian ini adalah pengaruh media sosial terhadap keterampilan menulis bahasa Jepang; dan tanggapan mahasiswa mengenai penggunaan media sosial terhadap pengembangan keterampilan menulis bahasa Jepang. Adapun batasan masalah dalam penelitian ini hanya meneliti media sosial email, WhatsApps dan Line.

\section{METODE PENELITIAN}

Metode yang digunakan pada penelitian ini adalah metode eksperimen. Karena penelitian ini bertujuan untuk mengetahui keefektifitas an dari suatu metode pengajaran dan pembelajaran, apabila hasilnya memberikan nilai positif dapat memberikan alternative modelpembelajaran untuk pembelajaran Menulis tingkat menengah (Chukyu Sakubun) (Sutedi, 2009: 54). Fokus permasalahan pada penelitian ini menitikberatkan pada perbaikan model pembelajaran dan strategi pengajaran pada mata kuliah menulis karangan tingkat menengah (Chuukyuu Sakubun).

Metode penelitian ini mencakup empat tahap, yaitu pengumpulan data, analisis data, pembahasan dan penyimpulan. Teknik yang digunakan untuk mengumpulkan data dalam penelitian ini yaitu teknik catat. Karena akan menelusuri data yang mewakili tema dan sesuai dengan pertanyaan penelitian yang diajukan. Waktu pelaksanaan kegiatan eksperimennya dari tahap persiapan sampai tahap refleksi keseluruhan ada enam bulan, dari bulan April sampai dengan bulan September 2019. Lokasi penelitian dilaksanakan di Departemen Pendidikan Bahasa Jepang FPBS UPI.

Penelitian ini melibatkan 25 orang mahasiswa salah satu perguruan tinggi negeri di Kota Bandung yang dipilih dengan teknik purposive-sampling. 
Sampel penelitian ini terdiri dari 11 mahasiswa laki-laki dan 14 mahasiswa perempuan. Rata-rata usia mahasiswa antara 19-20 tahun dan telah belajar bahasa Jepang 3 sampai 4 tahun lebih.

Instrumen pada penelitian ini menggunakan angket, soal tes sakubun, panduan wawancara, dan hasil komunikasi dengan responden melalui perangkat media sosial yaitu email, WhatsApp, Line. Ada dua angket yang akan diberikan, Angket 1 disebarkan pada saat pre test, digunakan untuk menghimpun informasi mengenai kondisi perkuliahan Menulis (Chuukyuu Sakubun) saat ini, kesulitan mahasiswa dalam menulis suatu karangan berbahasa Jepang. Dan Angket 2 disebarkan pada saat post test, digunakan untuk menghimpun informasi tanggapan mengenai model pembelajaran yang digunakan selama kegiatan eksperimen dan beberapa masukan / saran.

Tahapan dalam pengumpulan data yang dilakukan dengan diawali, (1) memilih perwakilan data penelitian; (2) mengumpulkan tulisan-tulisan hasil komunikasi dengan responden dalam media sosial yaitu dari email, WhatsApps dan Line yang berkaitan dengan feedback hasil sakubun; (3) mengklasifikasikan dan mengkategorisasikan bagian-bagian tulisan; (4) membaca literatur yang relevan dengan tema; (5) mencari artikel penelitian sebelumnya yang relevan dengan pertanyaan penelitian; (6) menganalisis tulisan-tulisan berbahasa Jepang; (7) menginterpretasikan data; dan (8) membuat kesimpulan.

\section{HASIL DAN PEMBAHASAN}

Kegiatan menulis merupakan proses dalam berkomunikasi, yang membedakan kegiatan menulis dengan kegiatan berbicara adalah lawan bicara yang dihadapi tidak secara langsung, sehingga respon yang didapat tidak secara langsung juga. Hal ini menyebabkan menulis terkadang dianggap sulit, karena kegiatan menulis adalah proses menyampaikan sesuatu pesan secara pasif kepada lawan bicara (Hyogyon, 2010). 
Pada studi pendahuluan yang telah dilaksanakan sebelum kegiatan eksperimen menunjukkan bahwa hanya sebagian kecil dari responden yang dapat menyelesaikan karangan/tulisan utuh dalam waktu 30 menit yang diberikan. Sedangkan $75 \%$ responden lainnya mayoritas hanya dapat membuat karangan dalam 1 paragraf saja. Setelah diperdalam dengan melakukan wawancara ternyata hal yang membuat responden tidak dapat menyelesaikan karangannya adalah ide cerita yang sulit dikembangkan yang kemudian dituangkan ke dalam karangan.

Kemudian langkah selanjutnya melakukan observasi ke kelas Chuukyuu Sakubun 2 (menulis tingkat menengah) pada tingkat 2 semester 4. Berdasarkan hasil observasi menunjukkan hal yang sama seperti pada penelitian sebelumnya bahwa mahasiswa masih kesulitan mengembangkan isi karangan walaupun telah dilakukan stimulus di awal pembelajaran dengan memberikan contoh karangan. Hal ini senada dengan hasil angket yang telah disebarkan.

Berdasarkan hasil angket (April 2019) menunjukkan bahwa 70\% mayoritas mahasiswa menganggap tahapan kegiatan mengembangkan ide cerita menjadi satu cerita utuh merupakan hal yang paling sulit dalam menulis/mengarang. Kemudian kesulitan dalam mengembangkan tulisan tersebut sebanyak 65\% dikarenakan diksi kata dan kurangnya kosa kata yang dimiliki, dan 25\% merupakan faktor kurang memahami struktur pola kalimat dan faktor lainnya 10\% mengenai koherensi antar kalimat.

Apabila dilihat dari penelitian sebelumnya, pada penelitian kali ini ditambahkan media komunikasi dengan menggunakan media sosial yang banyak digunakan mahasiswa yaitu WA dan Line. Ternyata hasil penelitian cukup mengalami peningkatan. Apabila dilihat dari hasil analisis karangan menunjukkan bahwa sebanyak 60\% dapat menyelesaikan karangan utuh dengan baik. Walaupun pada awal kegiatan masih agak sulit mengembangkan isi karangan karena tidak terbiasa menulis. 
Pada kenyataannya, sudah banyak strategi / teknik yang ditawarkan untuk meningkatkan kemampuan menulis diantaranya yang menggunakan teknik Peer Feedback. Oleh karenanya, tanggung jawab pengajar sebagai pendidik dalam memahamkan konsep menulis pada mahasiswa perlu ditingkatkan lagi. Sejalan dengan pendapat Kimura Muneo (1988) yang menegaskan bahwa pengajar adalah faktor yang memegang peranan penting dalam kegiatan menulis. Selain faktor materi, pembelajar, dan faktor eksternal lainnya. Beberapa hal ini diperlukan dalam menentukan kreativitas dari pengajar. Pada akhirnya daya kreativitas dan kemampuan pengajarlah yang pada akhirnya mempengaruhi pelaksanaan kegiatan belajar mengajar tercapai tujuan pembelajarnya.

Oleh karena itu, untuk menyikapi permasalahan yang menghambat dalam kegiatan menulis berbahasa Jepang dan untuk meningkatkan kualitas isi karangan digunakan teknik Peer Feedback, Peer Direct Feedback dan forum komunikasi untuk berdiskusi menggunakan media sosial email, WA dan Line. Teknik Peer Feedback, teknik ini berpusat pada kerjasama antar tutor sebaya atau disebut teman/partner, digunakan dalam kegiatan menulis untuk menyempurnakan hasil tulisannya melalui evaluasi / feedback yang dberikan oleh teman sejawat. Responden tidak hanya memberikan feedback saja, lebih dari itu, juga ada kegiatan mereviu karangan teman lalu memberikan kritik, saran dan sebagainya. Kemudian tahap berikutnya dilanjutkan dengan koreksian dan feedback dari pengajar dengan teknik Peer Direct Feedback dengan forum komunikasi melalui media sosial untuk menyempurnakan tulisan tersebut.

Berdasarkan hasil nilai pre-test dan post-test menunjukkan bahwa adanya peningkatan dalam hal mengembangkan isi karangan dan penyelesaian karangan utuh sebanyak 60\%. Tetapi apabila dilihat dari nilai rata-rata hasil karangan saat pre-test dan post-test Pada mulanya hasil pre-test mendapat disimpulkan bahwa pengaruh media sosial terhadap kemampuan menulis bahasa Jepang tidak terlalu signifikan, karena nilai rata-rata dibawah 
70 sebanyak 70\%. Dari pengamatan hasil komunikasi melalui media sosial hanya beberapa mahasiswa (sebanyak 30\%) yang menggunakan media sosial untuk bertanya jawab mengenai hasil feedback dan kesulitan menulis lainnya, selebihnya menggunakan media sosial hanya sebagai salah satu alat mengirimkan tugas tanpa memanfaatkan untuk memperbaiki dan mengembangkan hasil tulisannya.

Hal ini disebabkan karena dengan adanya media sosial yang digunakan sebagai alat komunikasi dan Peer Feedback melalui email, WA, dan Line. Dengan adanya media sosial ini mahasiswa dapat memberikan pengaruh yang sangat besar pada mahasiswa dalam menyelesaikan karangannya. Hal ini dapat dilihat mayoritas mahasiswa dapat langsung bertanya kepada dosen di saat mereka perlu berdiskusi dan dapat langsung direspon. Jadi pada saat ide mengembangkan karangan dapat dengan efektif dilakukan.

Tetapi setelah menggunakan media sosial sebagai forum komunikasi pada pertemuan keempat sampai pertemuan terakhir ternyata sebagian besar responden (90\%) berpendapat bahwa adanya media sosial sangat membantu dalam pengumpulan tugas Menulis yang bisa disetting waktu dan kemana pengumpulannya, dan hal ini bahkan bisa mengurangi penggunaan kertas (paperless). Selain itu, apabila ada kesulitan dapat dengan langsung berkomunikasi dengan pengajarnya. Lebih dari setengah jumlah responden (70\%) menanggapi positif dari penggunaan media sosial dalam meningkatkan kemampuan menulis.

Tetapi ada beberapa temuan dalam penelitian ini, masih banyak responden merasa kesulitan apabila berkomunikasi menggunakan bahasa perantaranya dengan bahasa Jepang. Hanya 30\% mahasiswa yang sudah menggunakan bahasa Jepang dalam berkomunikasi dengan dosennya, selebihnya hanya digunakan pada saat aisatsu saja dalam media sosial. Akhirnya sebagian besar memilih media sosial hanya sebagai alat 
pengumpulan tugas, mendapat feedback, merevisi, kemudian memberikan hasil revisi untuk dicek kembali hingga menjadi tulisan utuh yang baik.

Beberapa mahasiswa lamban dalam merespon tugas yang diberikan. Tetapi sebagian besar memberi respon yang baik setelah diberi feedback pada tugas 1, terutama mahasiswa dari kelompok tinggi berkemampuan bahasa Jepang baik. Hanya beberapa mahasiswa yang berkomunikasi atau menuliskan email yang menggunakan bahasa Jepang. Media sosial yang digunakan baru menggunakan email dan WA, media sosial yang paling sering dan mudah digunakan oleh responden.

\section{KESIMPULAN}

Pemanfaatan media sosial sebagai alat perantara komunikasi dalam pembelajaran menulis merupakan salah satu alternatif model pembelajaran yang dapat digunakan untuk menyiasati kurangnya pertemuan dalam kelas. Sehingga dalam proses pembelajaran mahasiswa melakukan kegiatan pembelajaran secara aktif dan mandiri (student center) tidak terpusat pada dosen/pengajar (teacher center). Ciri khas dalam pembelajaran menulis dengan teknik ini adalah adanya umpan balik yang diberikan langsung oleh mahasiswa kepada mahasiswa lain, mahasiswa dengan dosen, dosen dengan mahasiswa. Sehingga kegiatan koreksi hasil tulisan/karangan dapat tersampaikan secara langsung kepada penulis tidak seperti pembelajaran menulis biasanya yang hanya mengandalkan pemberian umpan balik dari dosen/pengajar yang diberikan secara tidak langsung di kelas.

Penggunaan media sosial ini sebagai media perantara dalam kegiatan belajar mengajar seperti dua sisi mata uang, ada sisi positif dan ada juga sisi negatifnya. Pengaruh positifnya adalah mahasiswa dapat mengetahui secara langsung kekuatan dan kelemahan dari tulisannya, karena hasil tulisannya diberikan feedback langsung oleh teman sejawat dan dosen melalui media sosial WA, Line dan email. Teman yang menjadi korektor menyampaikan 
secara langsung kalimat yang kurang tepat, koherensi antar kalimat, bahkan sampai isi kalimat yang tidak bisa dimengerti dari hasil karangan yang dibuat melalui saran dan komentar serta feedback. Dan apabila ada pertanyaan atau kesulitan bisa langsung ditanyakan melalui WA dn Line. Hal-hal positif ini bisa diakomodir dan dipenuhi melalui media sosial karena tidak terkekang oleh ruang dan waktu, berbeda halnya kalau mengandalkan pembelajaran menulis hanya di kelas saja. Tetapi sisi negatifnya adalah pengalihan fokus saat menggunakan media sosial adalah konsentrasi terganggu karena ingin lihat pesan lain atau melakukan hal lain selain kegiatan menulis. Jadi untuk penelitian selanjutnya akan diarahkan pada prosedur dan teknik penggunaan media sosial ini supaya meminimalisir pengaruh negatif dari media sosial yang tidak dapat dikontrol oleh pengajar dari kejauhan.

\section{REFERENSI}

Bakeer, A. M. (2018). Effects of information and communication technology and social media in developing students' writing skill: A case of Al-Quds open university. International Journal of Humanities and Social Science, 8(5), 45-53. https://doi.org/10.30845/ijhss.v8n5p5

Boyd, D. M., \& Ellison, N. B. (2007). Social network sites: Definition, history, and scholarship. Journal of Computer-Mediated Communication, 13(1), 210-230. https://doi.org/10.1111/i.1083-6101.2007.00393.x

Ellis, N. C., \& Schmidt, R. (1997). MORPHOLOGY AND LONGER DISTANCE DEPENDENCIES: Laboratory research illuminating the A in SLA. Studies in Second Language Acquisition, 19(2), 145-171.

https://doi.org/10.1017/S0272263197002027

Gamage, G. H. (2003). Issues in strategy classifications in language learning: a framework for kanji learning strategy research. ASAA e-journal of Asian linguistics and language teaching, issue no.3.

Grabe, W., \& Kaplan, R. B. (1996). Theory and practice of writing: An applied linguistic perspective. Longman. 
Hyland, F. (1998). The impact of teacher written feedback on individual writers. Journal of Second Language Writing, 7(3), 255-286. https://doi.org/10.1016/S1060-3743(98)90017-0

Hyland, F., \& Hyland, K. (2001). Sugaring the pill: Praise and criticism in written feedback. Journal of Second Language Writing, 10, 185-212. https://doi.org/10.1016/S1060-3743(01)00038-8

Hyogyon, K. (2010). Kaku koto o oshieru. The Japan Foundation.

Mori, Y. (2008). Epistemological beliefs and language learning beliefs: What do language learners believe about learning? Language Learning 49, 377 415. https://doi.org/10.1111/0023-8333.00094

Mori, Y., \& Shimizu, H. (2007). Japanese language students' attitudes toward kanji and their perceptions on kanji learning strategies. Foreign Language Annals 40, 472-490.

Muneo, K. (1988). Kyoujuhou nyuumon. Bojinsha.

Okita, Y. (1995). Kanji gakushuu sutoratejii to gakusei no kanji gakushuu ni taisuru shinnen [Kanji learning strategies and student beliefs on kanji learning]. Sekai no Nihongo Kyooiku [Japanese Language Education Around the Globe], 5, 105-124.

Sakkir, G. (2016). Interest and writing skill of the university students on using social media Facebook in writing class (STKIP Muhammadiyah Rappang, Indonesia). The Asian EFL Journal, Second Language Acquisition - Academic Research, TESOL Indonesia International Conference Edition. ISSN: 1738-1460, December 2016, Volume 2, pp. 178-188.

Sakkir, G. (2018). Pengembangan modul pengajaran menulis berbasis Facebook. Doctoral dissertation, Pascasarjana.

Sakkir, G., \& Abrar, A. E. Y. (2018). Students' perception of the implementation Facebook group in learning writing skill. The $65^{\text {th }}$ TEFLIN International Conference, Universitas Negeri Makasar, Indonesia, 12-14 July 2018, pp.30-34.

Shazali, S. S., Shamsudin, Z. H., \& Yunus, M. M. (2019). Instagram: Platform to develop student's writing ability. International Journal of Academic Research in Business and Social Sciences, 9(1), 88-98.

Sutedi, D. (2009). Penelitian pendidikan bahasa Jepang. Humaniora Utama Press. 
Sutjiati, N. \& Rasiban, L. M. (2016). Project-based learning sebagai upaya meningkatkan kreatifitas menulis karangan pendek bahasa Jepang. Proceeding Maranatha International Conference on Language, Literature and Culture, 24-25 November 2016. p.446-456.

Tess, P. A. (2013). The role of social media in higher education classes (real and virtual)-A literature review. Computers in Human Behavior, 29(5), A60-A68.

Toyoda, E. (1995). Learner's feelings toward kanji study. Nihongo Kyouiku, 85, 101-113.

Yahya, M. Y., \& Hashim, N.H. (2013) DIFFICULTIES AND WAYS TO IMPROVE ENGLISH WRITING SKILLS AMONG POSTGRADUATE ESL STUDENTS, ICERI2013 Proceedings, 6245-6252. 